\title{
Guidelines for collection of biological samples for giant otters (Pteronura brasiliensis Gmelin, 1788) and Neotropical otters (Lontra longicaudis Olfers, 1818)
}

\author{
Mariana Malzoni Furtado ${ }^{1,2, *}$, Livia de Almeida Rodrigues ${ }^{3}$, Rodrigo Hidalgo Friciello \\ Teixeira ${ }^{4}$ and Miriam Marmontel ${ }^{5}$ \\ IInstituto Onça-Pintada/Jaguar Conservation Fund, Caixa Postal 193, 75830-000 Mineiros GO, Brazil \\ ${ }^{2}$ Giant Otter Conservation Fund, Rua Coronel Dulcídio 1857, Bairro Água Verde, 80250-100 Curitiba PR, Brazil \\ ${ }^{3}$ Centro Nacional de Pesquisa e Conservação de Mamíferos Carnívoros/ICMBio, \\ Estrada Hisaichi Takebayaishi 8600, 12952-011 Atibaia SP, Brazil \\ ${ }^{4}$ Zoológico Municipal de Sorocaba, Rua Teodoro Kasiel 883, Vila Hortência, 18020-268 Sorocaba SP, Brazil \\ 5Instituto de Desenvolvimento Sustentável Mamirauá, Estrada do Bexiga 2584, 69553-225 Tefé AM, Brazil
}

*Corresponding author: marianafurtado@jaguar.org.br

Giant (Pteronura brasiliensis) and Neotropical (Lontra longicaudis) otters are semi-aquatic mustelids of the Brazilian fauna. As one of the top predators of aquatic systems' food web, they play an important role in ecosystem balance. The giant otter is globally classified as Endangered (Rodrigues et al., 2013; Groenendijk et al., 2015), whereas the Neotropical otter is considered Near Threatened (Rheingantz and Trinca, 2015). In Brazil, both species occur currently in the Amazon, Cerrado and Pantanal biomes; the Neotropical otter also occurs in the Atlantic Forest and Pampas. The main anthropic threats to the species are hunting, habitat fragmentation, human conflicts, and contamination of water bodies (Groenendijk et al., 2015; Rheingantz and Trinca, 2015). Several studies on the ecology and conservation of these species have been carried out in recent decades (Koepfli and Wayne, 1998; Astúa et al., 2010; Cabral et al., 2010; Oliveira et al., 2011; Rheingantz et al., 2011; Pickles et al., 2012; Leuchtenberger et al., 2018). However, many knowledge gaps regarding basic information about giant otters remain, and even more so for Neotropical otters.

Keywords:

Brazilian fauna, health evaluation, mustelids, necropsy, protocol, veterinary

ARTICLE INFO
Manuscript type: Protocol
Article History
Received: 23 May 2021
Received in revised form: 12 September 2021
Accepted: 12 September 2021
Available online: 12 November 2021
Responsible Editor: Nataly Castelblanco-Martinez
Citation:
Furtado, M.M., Rodrigues, L.A., Teixeira, R.H.F. and Marmontel,
M. (2021) Guidelines for collection of biological samples for giant
otters (Pteronura brasiliensis Gmelin, 1788) and Neotropical otters
(Lontra longicaudis Olfers, 1818). Latin American Journal of Aquatic
Mammals 16(1): $54-60$. https://doi.org/10.5597/lajam00273

In 2010, one of the strategies by the Ministry of the Environment (MMA) for the conservation of Brazilian fauna (Ordinance ICMBio $n^{\circ} 43 / 2014$ ) was to develop the first National Action Plan (NAP) for giant otters, which also included Neotropical otters (ICMBio/MMA, 2010). The NAP Giant Otter recognized the need to standardize protocols for collection, processing, and storage of otter biological samples to improve and optimize capture, handling, and necropsy efforts of both species of otters. Standardized animal care and veterinary guidelines for otters in zoos, aquariums, rehabilitation, and wildlife centers and a postmortem protocol for otters have previously been described (Simpson, 2001; AZA Small Carnivore TAG, 2008; Myers, 2012).

Developed by veterinarians with experience in wildlife, members of the Technical Advisory Group of the National Action Plan for Conservation of Giant Otters (TAG/NAP Giant Otter) coordinated by the Centro Nacional de Pesquisa e Conservação dos Mamíferos Carnívoros (ICMBio/CENAP) and reviewed by other otter specialist members of the Group, these protocols are intended for biologists, field veterinarians and other professionals involved in conservation who are working with these species. The use of these guidelines will be helpful to optimize the health evaluation of otters in the wild and under human care, understand the epidemiology of diseases in otters, guarantee the quality of the information collected, and maximize the efforts in research projects.

Two protocols were developed: 1) collection, processing, and storage of biological samples from live giant and Neotropical otters, and 2) collection of biological material during necropsy. We emphasize that each step mentioned in these protocols must be properly performed to maintain the quality of the biological samples until they arrive in laboratories for analysis.

1) Protocol for collection, processing, and storage of biological samples from live giant and Neotropical otters

The biological samples described here can be collected from anesthetized individuals (Figs $1 \mathrm{a}, 1 \mathrm{~b}$ and $1 \mathrm{c}$ ) or directly from the field (e.g. feces and hair). Table 1 presents samples and suggested quantity to be collected, equipment needed, the most appropriate collection method, processing, storage, and laboratory 


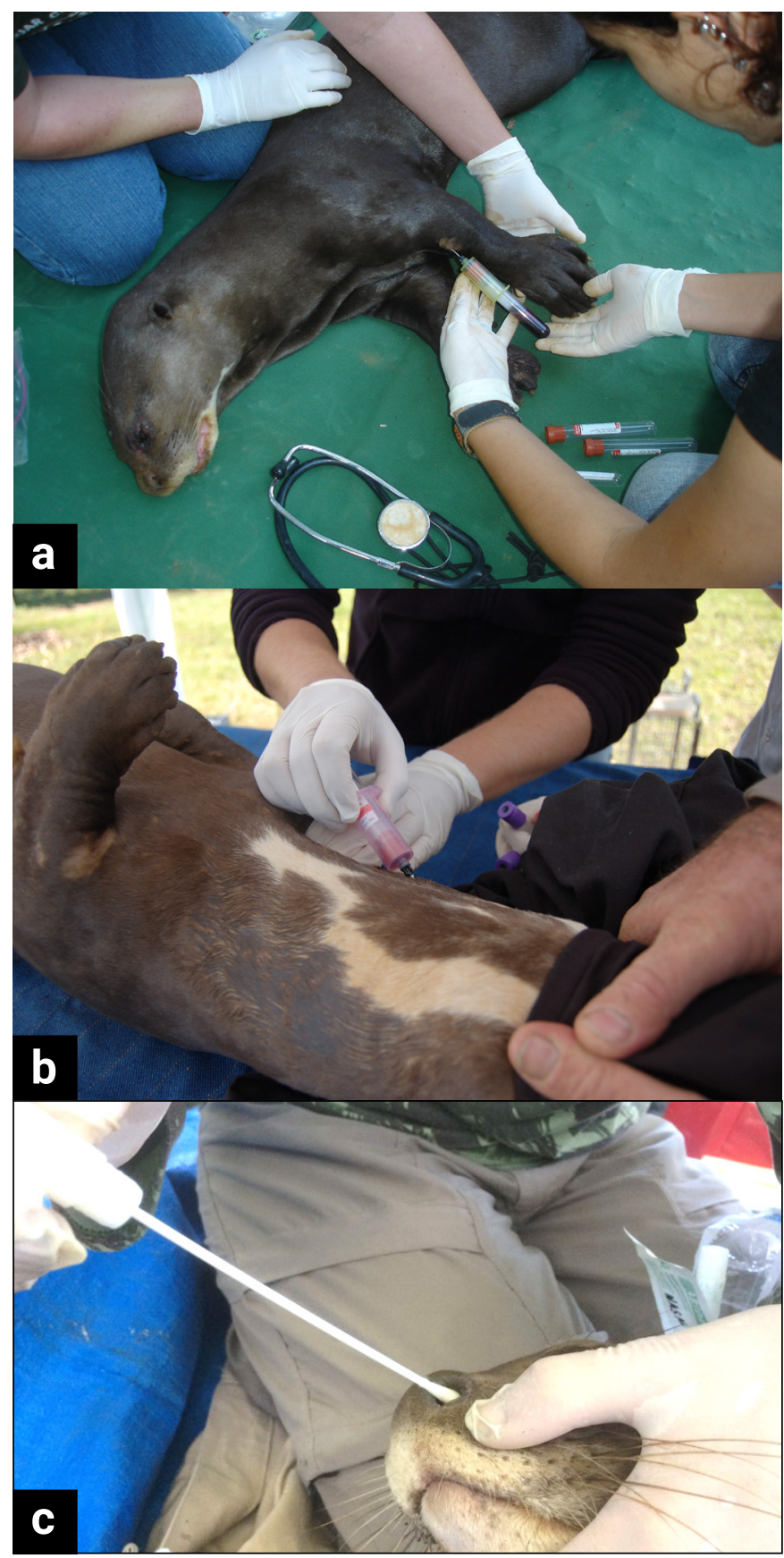

Figure 1. Collection of biological samples of live giant otter (Pteronura brasiliensis). a) Blood sample collection from the cephalic vein; b) Blood sample collection from the jugular vein; $c$ ) Nasal secretion collection with a sterile swab. (Photo 1a: Jaguar Conservation Fund/Instituto Onça-Pintada; Photo 1b: Caroline Leuchtenberger/ Instituto Farroupilha; Photo 1c: Grazielle Soresini/ Giant Otter Conservation Fund).

analyses to be performed. We present an ideal situation and recognize that many factors may prevent the professional from following the full protocol; therefore, this should be viewed as a guide to be adapted according to each particular situation.

All samples must contain information on species, sex, estimated age, date of collection, capture site with geographical coordinates, identification of the animal and person responsible for collection (Fig. 2). We recommend using a system where each animal receives a unique ID number that provides a rapid code and facilitates the identification. Animal ID should be assigned as the example in Fig. 3.

During events of captures/anesthesia of giant and Neotropical otters, the professional should strive to collect the additional information described in Table 2. Anesthesia protocols in giant otters and recommendations for anesthesia procedures are available in the literature (AZA Small Carnivore TAG, 2008; Silveira et al., 2011; Myers, 2012; Duplaix et al., 2015) and we recommend that it should be performed with care and responsibility by experienced veterinarians.

2) Protocol for the collection of biological material during necropsy in giant and Neotropical otters

Necropsy should be performed as soon as possible after the animal's death is confirmed. In the latter case, the carcass can be refrigerated at $4-8{ }^{\circ} \mathrm{C}$ for up to $24-36 \mathrm{~h}$. Freezing should be performed only when the necropsy is unfeasible in a timely manner, as it causes the physical rupture of most cell membranes. Protective clothing such as latex gloves, protective mask, and coveralls should be used to perform the necropsy. Photographing external and internal lesions provides a record of the changes observed in the examined organs (Figs $6 \mathrm{a}, 6 \mathrm{~b}$ and $6 \mathrm{c}$ ).

Biological materials must be stored according to the type of research to be conducted. It is important to note that tissues preserved in formaldehyde must not be frozen, and samples for infectious or toxicological diseases must be frozen or refrigerated. The samples must be collected in clean (or sterile), sealed and identified vials/containers (Fig. 7). The necropsy should preferably be performed following the steps described below (Matushima, 2007; Catão-Dias and Miranda, 2014).

\section{a) General examination}

Assess the physical condition of the animal: observe the presence of lesions, parasites, signs of predation, bruises, fractured bones, and signs of trauma that could have been the cause of death. Differentiate between postmortem injuries caused by scavengers. Assess the nutritional status and dental arch of the animal. Include a detailed photograph of the dental arch.

\section{b) Collection of skin ectoparasites}

Through manual rotation. Store in vial or tube with $70 \%$ alcohol at room temperature.

\section{c) Aseptic collection of cardiac blood}

After opening the chest cavity, perform aseptic collection of cardiac blood with a syringe and needle. The blood must be transferred to a culture bottle and refrigerated.

\section{d) Collection of material for microbiological examination}

Samples for microbiological analysis must be collected before manipulating the organs. Tissue fragments of $3 \mathrm{~cm}^{3}$ should be collected with sterile material as swabs or sterile syringes. Samples must be kept refrigerated and Stuart or Amies transport medium can be used. To improve the research, samples for microbiome can also be collected from the organs in a sterile swab, stored in an Eppendorf tube and frozen.

e) Collection of material for histopathological examination

Fragments of a maximum of $2 \mathrm{~cm}^{3}$ from all organs must be collected with a scalpel or a sharp knife. Preferably, samples 
Table 1. Protocol for collection, processing, and storage of biological samples from live giant and Neotropical otters.

\begin{tabular}{|c|c|c|c|c|c|c|}
\hline SAMPLE & $\begin{array}{l}\text { MATERIAL } \\
\text { SUPPLIES }\end{array}$ & $\begin{array}{c}\text { NBR } \\
\text { SAMPLES } \\
\text { (QUANTITY) }\end{array}$ & METHOD OF COLLECTION & PROCESSING & STORAGE & ANALYSES \\
\hline \multirow[t]{3}{*}{ Blood } & \multirow{3}{*}{$\begin{array}{l}\text { Tube with } \\
\text { anticoagulant } \\
\text { (EDTA) (purple top } \\
\text { tube)* }\end{array}$} & \multirow[t]{3}{*}{$12 \mathrm{ml}$} & \multirow[t]{3}{*}{ Venous puncture } & \multirow{3}{*}{$\begin{array}{l}\text { Homogenize and } \\
\text { keep at room } \\
\text { temperature up to } \\
12 \mathrm{~h} \text { preferably, but no } \\
\text { longer than } 24 \mathrm{~h} \text {, then } \\
\text { refrigerate. }\end{array}$} & Up to 24 hours after collection & $\begin{array}{l}\text { Blood count } \\
\text { Hematocrit }\end{array}$ \\
\hline & & & & & $\begin{array}{l}\text { Aliquot in } 0.6 \mathrm{ml} \text { Eppendorf, } \\
\text { freeze at }-20^{\circ} \mathrm{C} \text { or }-80^{\circ} \mathrm{C} \text { when } \\
\text { available }\end{array}$ & $\begin{array}{l}\text { Pathogens } \\
\text { detection }\end{array}$ \\
\hline & & & & & $\begin{array}{l}\text { 1:1 Easy Blood Buffer. } \\
\text { Homogenize, aliquot in } 0.6 \mathrm{ml} \\
\text { Eppendorf, freeze at }-20^{\circ} \mathrm{C}\end{array}$ & Genetic analysis \\
\hline \multirow[t]{3}{*}{ Blood } & \multirow{3}{*}{$\begin{array}{l}\text { Tube without } \\
\text { anticoagulant (red } \\
\text { top tube) }\end{array}$} & \multirow[t]{3}{*}{$30 \mathrm{ml}$} & \multirow[t]{3}{*}{ Venous puncture } & \multirow{3}{*}{$\begin{array}{l}\text { Keep at room } \\
\text { temperature up to } \\
12 \mathrm{~h} \text { preferably, but no } \\
\text { longer than } 24 \mathrm{~h} \text {, then } \\
\text { refrigerate. }\end{array}$} & \multirow{3}{*}{$\begin{array}{l}\text { Separate the serum and } \\
\text { aliquot in } 0.6 \mathrm{ml} \text { Eppendorf; } \\
\text { freeze at }-20^{\circ} \mathrm{C}\end{array}$} & Serosurvey \\
\hline & & & & & & $\begin{array}{l}\text { Hormonal } \\
\text { analysis } \\
\end{array}$ \\
\hline & & & & & & $\begin{array}{l}\text { Biochemical } \\
\text { analysis }\end{array}$ \\
\hline Blood & $\begin{array}{l}\text { Filter paper or } \\
\text { tube with ethanol }\end{array}$ & 1-2 drops & $\begin{array}{l}\text { Blood from the syringe } \\
\text { and needle used for blood } \\
\text { collection }\end{array}$ & $\begin{array}{l}\text { Drip one or two drops } \\
\text { of blood on the filter } \\
\text { paper or inside the } \\
\text { tube with ethanol }\end{array}$ & Room temperature & Genetic analysis \\
\hline Blood smear & Microscope slide & 2 & $\begin{array}{l}\text { Venous puncture (from } \\
\text { tubes with or without } \\
\text { anticoagulant) }\end{array}$ & $\begin{array}{l}\text { Dry } \\
\text { Preserve with } \\
\text { methanol }\end{array}$ & $\begin{array}{l}\text { Room temperature } \\
\text { Box of slides or wrapped } \\
\text { in tissue paper (room } \\
\text { temperature) }\end{array}$ & $\begin{array}{l}\text { Hemoparasite } \\
\text { detection }\end{array}$ \\
\hline \multirow[t]{2}{*}{ Hair } & \multirow[t]{2}{*}{ Plastic bag } & 1 & $\begin{array}{l}\text { Manual traction, no need to } \\
\text { come with the bulb }\end{array}$ & - & Freeze at $-20^{\circ} \mathrm{C}$ & Heavy metals \\
\hline & & $\overline{1}$ & $\begin{array}{l}\text { Manual traction, the hair } \\
\text { needs to come with the bulb }\end{array}$ & - & Freeze at $-20^{\circ} \mathrm{C}$ & Genetic analysis \\
\hline \multirow[t]{3}{*}{ Urine } & \multirow[t]{3}{*}{$15 \mathrm{ml}$ sterile vial } & \multirow[t]{3}{*}{1} & \multirow[t]{3}{*}{ Catheter } & \multirow[t]{3}{*}{-} & Up to 24 hours after collection & Urinalysis \\
\hline & & & & & $\begin{array}{l}\text { Aliquot in } 1.5 \mathrm{ml} \text { Eppendorf, } \\
\text { freeze at }-20^{\circ} \mathrm{C}\end{array}$ & $\begin{array}{l}\text { Pathogen } \\
\text { detection }\end{array}$ \\
\hline & & & & & $\begin{array}{l}1: 1 \text { potassium dichromate } \\
2 \% \text {. Refrigerate or room } \\
\text { temperature }\end{array}$ & $\begin{array}{l}\text { Endoparasite } \\
\text { detection }\end{array}$ \\
\hline \multirow[t]{8}{*}{ Feces } & \multirow[t]{7}{*}{$\begin{array}{l}\text { Universal collector } \\
\text { or } 50 \mathrm{ml} \text { Falcon tube }\end{array}$} & \multirow[t]{7}{*}{1} & \multirow[t]{7}{*}{ Directly from the rectum } & \multirow[t]{7}{*}{-} & Freeze at $-20^{\circ} \mathrm{C}$ & $\begin{array}{l}\text { Pathogen } \\
\text { detection }\end{array}$ \\
\hline & & & & & $\begin{array}{l}1: 1 \text { potassium dichromate } \\
2 \% \text {. Refrigerate or room } \\
\text { temperature } \\
\end{array}$ & $\begin{array}{l}\text { Endoparasite } \\
\text { detection }\end{array}$ \\
\hline & & & & & $\begin{array}{l}\text { Merthiolate-lodine- } \\
\text { Formaldehyde (MIF) (when } \\
\text { parasitological examination is } \\
\text { performed later than } 24 \mathrm{~h} \text { after } \\
\text { collection) }\end{array}$ & $\begin{array}{l}\text { Parasitological } \\
\text { analysis }\end{array}$ \\
\hline & & & & & $\begin{array}{l}\text { Absolute alcohol or 1:3 silica. } \\
\text { Refrigerate or freeze as soon } \\
\text { as possible (only fresh feces) }\end{array}$ & $\begin{array}{l}\text { Molecular } \\
\text { analysis }\end{array}$ \\
\hline & & & & & $\begin{array}{l}\text { Fresh feces or mucus - } \\
\text { refrigerate as quickly as }\end{array}$ & $\begin{array}{l}\text { Hormonal } \\
\text { analysis }\end{array}$ \\
\hline & & & & & possible & \\
\hline & & & & & Room temperature & Diet analysis \\
\hline & Sterile swab & 1 & Directly from the rectum & - & Freeze at $-20^{\circ} \mathrm{C}$ & $\begin{array}{l}\text { Microbiome } \\
\text { characterization }\end{array}$ \\
\hline Mucus & $\begin{array}{l}\text { Universal collector } \\
\text { or } 50 \mathrm{ml} \text { Falcon tube }\end{array}$ & 1 & Manual collection & - & $\begin{array}{l}\text { Absolute alcohol or 1:3 silica. } \\
\text { Refrigerate or freeze as soon } \\
\text { as possible (only fresh feces) }\end{array}$ & $\begin{array}{l}\text { Molecular } \\
\text { analysis }\end{array}$ \\
\hline \multirow[t]{2}{*}{ Milk } & Eppendorf & - & Manual extraction & - & Freeze at $-20^{\circ} \mathrm{C}$ & $\begin{array}{l}\text { Analysis of milk } \\
\text { composition }\end{array}$ \\
\hline & Sterile swab & - & Manual extraction & - & Freeze at $-20^{\circ} \mathrm{C}$ & $\begin{array}{l}\text { Microbiome } \\
\text { characterization }\end{array}$ \\
\hline $\begin{array}{l}\text { Microbiological } \\
\text { samples }\end{array}$ & $\begin{array}{l}\text { Sterile swab (with } \\
\text { culture for virus, } \\
\text { fungus and bacteria) }\end{array}$ & 1 & $\begin{array}{l}\text { Rotate in mouth, ear, nose, } \\
\text { lesion }\end{array}$ & - & $\begin{array}{l}\text { Virus: freeze at }-20^{\circ} \mathrm{C} \\
\text { Fungus and microbiology: } \\
\text { refrigerate }\end{array}$ & $\begin{array}{l}\text { Pathogen } \\
\text { detection }\end{array}$ \\
\hline Vaginal citology & $\begin{array}{l}\text { Swab/Microscope } \\
\text { slide }\end{array}$ & 2 & Rotate in the vaginal canal & Preserve in methanol & Room temperature & $\begin{array}{l}\text { Reproductive } \\
\text { analysis }\end{array}$ \\
\hline Ectoparasites & $\begin{array}{l}\text { Vial or tube with } 70 \% \\
\text { alcohol }\end{array}$ & $\begin{array}{l}\text { as many as } \\
\text { possible }\end{array}$ & Manual rotation & - & Room temperature & $\begin{array}{l}\text { Ectoparasite } \\
\text { detection }\end{array}$ \\
\hline \multirow[t]{2}{*}{ Biopsies } & \multirow[t]{2}{*}{ Skin, muscle, lesion } & \multirow[t]{2}{*}{1} & \multirow[t]{2}{*}{ Disposable punch } & \multirow[t]{2}{*}{-} & $\begin{array}{l}\text { Skin and muscle: absolute } \\
\text { alcohol }\end{array}$ & Genetic analysis \\
\hline & & & & & $\begin{array}{l}\text { Skin and muscle: } 70 \% \text { alcohol } \\
\text { Lesion: freeze/formaldehyde } 10 \%\end{array}$ & $\begin{array}{l}\text { Microbiological } \\
\text { analysis }\end{array}$ \\
\hline
\end{tabular}

*tubes with anticoagulant sodium citrate (blue top), sodium heparine (green top), sodium fluoride (gray top) can be added for coagulation, blood gas and blood glucose tests, according to the focus of the study. 
Table 2. Additional information associated with collecting biological material from anesthetized giant and Neotropical otters.

\begin{tabular}{|c|c|}
\hline DATA & HOW TO PERFORM THE COLLECTION \\
\hline Weight & Weighing of the animal using a Pesola ${ }^{\odot}$ spring balance \\
\hline Biometrics & $\begin{array}{l}\text { Head length, Head circumference, Neck circumference, Ear length, Ear width, Chest circumference, Body length without tail, Tail length, Height, } \\
\text { Length and Width of hind and front paw (Fig. 4), Length of the right and left testicle (males; Fig. 5a), Width of the right and left testicle and perianal } \\
\text { gland length (males) } \\
\text { For females: note reproductive status and condition of the mammary glands }\end{array}$ \\
\hline $\begin{array}{l}\text { Coat pattern } \\
\text { (giant otters) }\end{array}$ & Photo of the throat pattern (Fig. 5b) \\
\hline Dentition & $\begin{array}{l}\text { Photos of the dental arch in occlusion: front, right side (Fig. 5c), left side, right diagonal and left diagonal } \\
\text { Photo of the open dental arch: front, right diagonal and left diagonal. } \\
\text { Dental formula }\end{array}$ \\
\hline $\begin{array}{l}\text { Physiological } \\
\text { parameters }\end{array}$ & During anesthesia, every 10 minutes record respiratory rate (breaths per minute), heart rate (heart beats per minute), and rectal temperature $\left({ }^{\circ} \mathrm{C}\right.$ ) \\
\hline
\end{tabular}

of normal tissues and injured tissues should be collected. The fragments must be stored in containers with $10 \%$ formaldehyde in a 1:9 ratio (fragment:formaldehyde). Never freeze.

\section{f) Collection of material for toxicological analysis}

Indicate when animal contact with toxic agents is suspected. It is recommended to collect $100 \mathrm{~g}$ of stomach contents, liver and kidney; and $50 \mathrm{ml}$ of blood in a clean and dry container. The material can be refrigerated or frozen. If the toxic agent involved is suspected, it should be indicated to the laboratory. Bones can also be an option for toxicological analysis. It is preferable to use long bones as femur, humerus, radius, ulna or tibia, and ribs. After collection, bones should be cleaned of all soft tissues, muscular insertions and periosteum, and then washed in a saline

Species:

Date of collection:

Animal identification:

Sex: Age:

Material collected:

Capture site:

Geographic coordinates:

Datum:

Responsible for

collection:



Figure 2. Model of label to be attached to each sample collected.

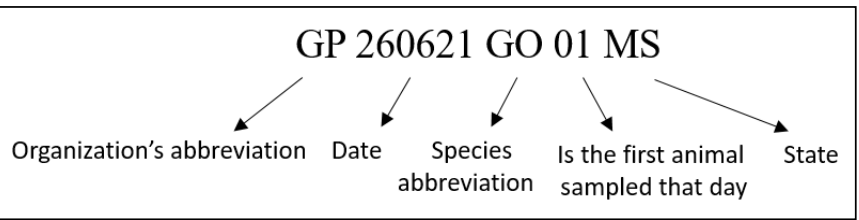

Figure 3. Animal ID. The first two letters indicate the organization that performed the biological collection. The first six numbers indicate the date (in the format DAY-MONTH-YEAR). The next two letters designate the species, GO for giant otters and NO for Neotropical otters. The next two digits indicate the counter of animals sampled that date. The last two letters designate the Brazilian state where the collection was performed. solution with gentamicin and stored in a tightly closed sterile plastic container and frozen at $-20^{\circ} \mathrm{C}$.

g) Collection of material for parasitological analysis

Feces must be collected directly from the rectum and preserved in $10 \%$ formaldehyde. Observe the presence of gastro-intestinal parasites, collect the individuals carefully with the aid of tweezers and store them in vial or tube with $70 \%$ alcohol. A portion of the feces can also be frozen for carrying out a barcoding of some life stages of the parasites.

h) Collection of material for genetics analysis

Collect at least three fragments about $1 \times 1 \mathrm{~cm}$ from the following organs: skeletal muscle, heart, liver, and kidney. Store in tubes with $70 \%$ alcohol.

Collect hair by manual traction and store dry in plastic bags or paper envelopes. Blood droplets are placed on filter paper or in Eppendorf tube with ethanol and stored at room temperature.

After all the necropsy steps have been carried out, the necropsy report sheet must be prepared according to the following model (Fig. 8). Upon completion of the necropsy, the remains of tissues must be buried or incinerated. Surgical instruments must be cleaned with soap and disinfected with $70 \%$ ethyl alcohol and the environment with sodium hypochlorite or bleach. The carcass must be buried for later retrieval or macerated or placed in a

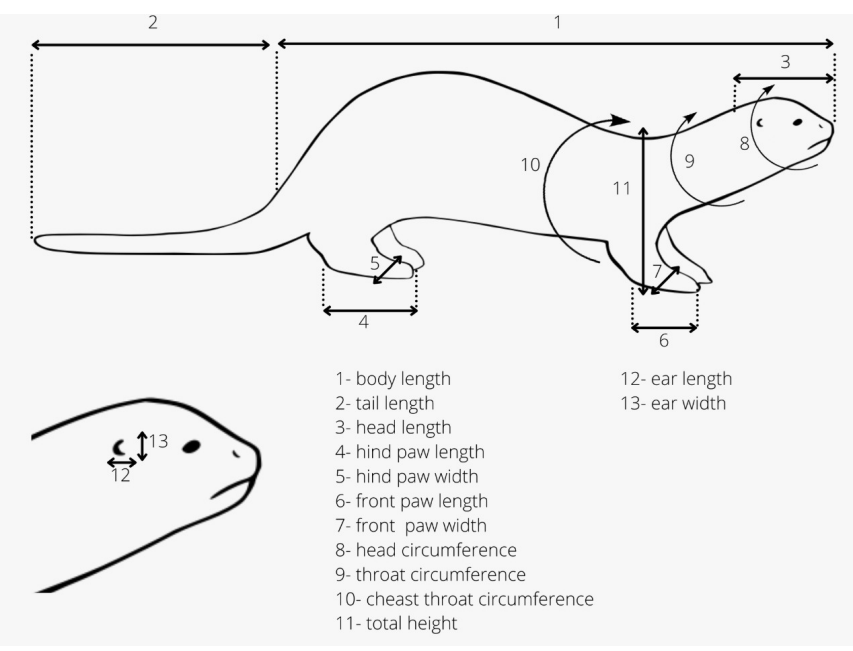

Figure 4. Measuring giant and Neotropical otters. Adapted from Geraci and Lounsbury (1993; Caroline Leuchtenberger/Instituto Farroupilha). 




Figure 5. a) Measuring the length of the testicle in a live male giant otter (Pteronura brasiliensis); b) Photo of throat pattern; c) Photo of the right side of the dental arch. (Photo 5a: Jaguar Conservation Fund/Instituto Onça-Pintada; Photos 5b-c: Caroline Leuchtenberger/ Instituto Farroupilha).

dermestid beetle bed such as to clean the skeleton for accession in a museum or research collection.

The use of standardized protocols suggested here for giant and Neotropical otters can contribute to expand the knowledge on health of the species and allow data comparison by different researchers/professionals in different locations. Researchers should be aware that any procedure with otters in the wild or under human care requires an environmental permit for handling, collecting, and transporting the biological material. The health evaluation of otter populations, and the knowledge on the cause of death of individuals will allow

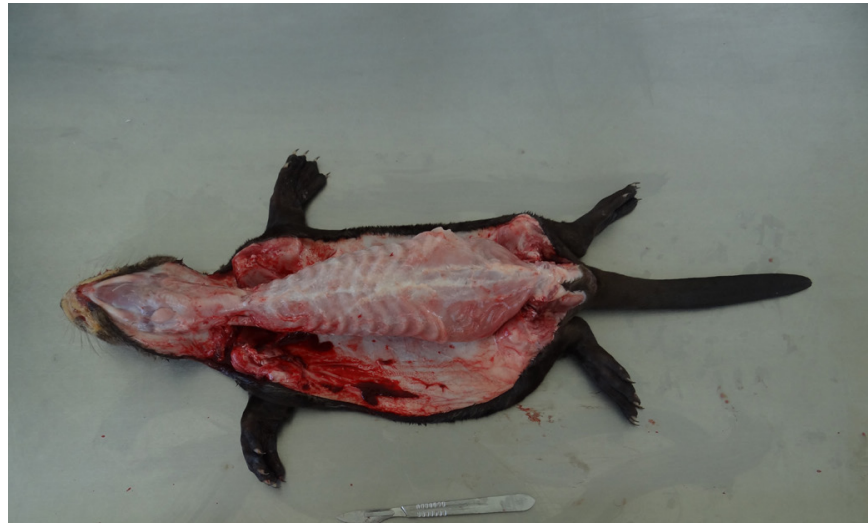

a

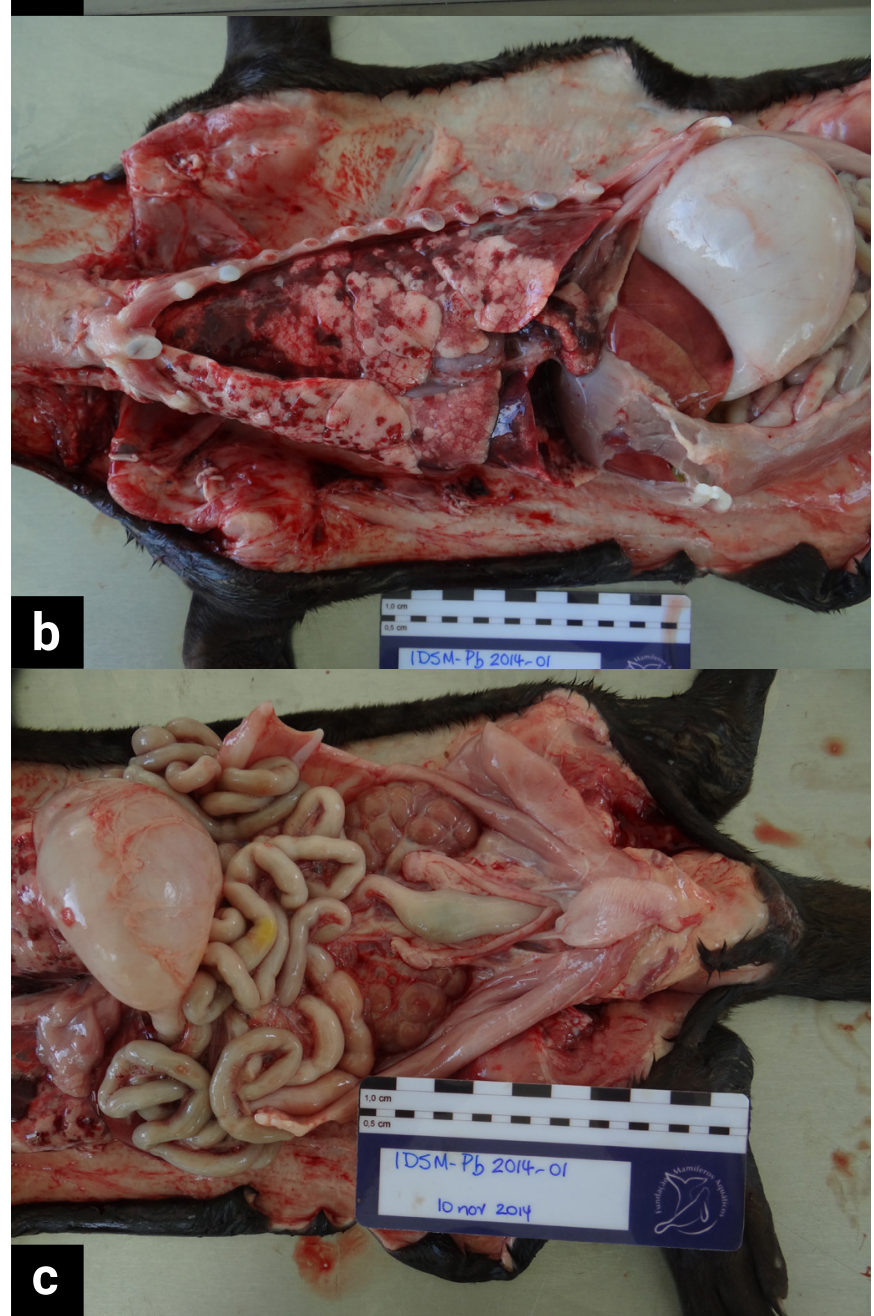

Figure 6. Necropsy of a giant otter (Pteronura brasiliensis) cub. a) Ventral view; b) Thoracic and abdominal cavity and major internal organs; c) Major internal organs of the abdominal cavity. (All photos: André Coelho, Instituto Mamirauá).

to identify possible pathogens circulating in the species, and in the long term, recognize which agents are endemic and how they might threaten the species. In addition, these guidelines can provide recommendations for epidemiological management strategies for the conservation of the species using standardized protocols and diagnoses obtained. 
Species:

Date and time of collection:

Date and time of death:

Animal identification:

Sex: Age:

Material collected:

Place of death:

Geographic coordinates:

Datum:

Responsible for collection:

Figure 7. Model of label to be attached to each sample collected at necropsy.

\section{ACKNOWLEDGMENTS}

We thank Caroline Leuchtenberger, Claudia Cavalcante Rocha Campos, Cristine Silveira Trinca, Guilherme de Miranda Mourão, Marcelo Lima Reis, Marcelo Lopes Rheingantz, Juliana Quadros, George Georgiadis and Rose Lilian Gasparini Morato, participants and collaborators of the Technical Advisory Group for the National Action Plan for Giant Otter Conservation of the Centro Nacional de Pesquisa e Conservação de Mamíferos Carnívoros (ICMBio/ CENAP) by reviewing the protocols.

\section{REFERENCES}

Astúa, D., Asfora, P.H., Aléssio, F.M. and Langguth, A. (2010) On the occurrence of the Neotropical Otter (Lontra longicaudis) (Mammalia, Mustelidae) in Northeastern Brazil. Mammalia 74: 213-217. https://doi.org/10.1515/MAMM.2010.004

AZA Small Carnivore TAG (2008) Stardardized Animal Care Guidelines for Otters (Lutrinae), version 2. Association of Zoos and Aquariums, Silver Spring, MD. 128 pp.

Cabral, M.M.M., Zuanon, J.A.S., de Mattos, G.E. and Rosas, F.C.W. (2010) Feeding habits of giant otters Pteronura brasiliensis (Carnivora: Mustelidae) in the Balbina hydroelectric reservoir, Central Brazilian Amazon. Zoologia 27(1): 47-53. https://doi.org/10.1590/S1984-46702010000100008

Catão-Dias, J.L. and Miranda, F. (2014) Considerações para realização e documentação de necropsias. Pages 1565-1576 in Cubas, Z.S., Silva, J.C.R. and Catão-Dias, J.L. (Eds) Tratado de Animais Selvagens: Medicina veterinária. 2ed. Editora Roca, São Paulo, Brazil.

Duplaix, N., Heap, C.J., Schmidt, T., Schikora, T., Carvalho, J., Rubiano, I., laleggio, D. and Rivera, S. (2015) Summary of Husbandry Guidelines for Giant Otters (Pteronura brasiliensis) in Zoos, Aquariums, \& Wildlife Sanctuaries. IUCN/SSC Otter Specialist Group, OZ Task Force. http://www.otterspecialisgroup. org/Library/TaskForces/OCT.html

Geraci, J.R. and Lounsbury, V.J. (1993) Marine Mammals AshoreA Field Guide for Strandings. A Texas A\&M Sea Grant Publication, USA. $344 \mathrm{pp}$.

\section{Necropsy report sheet}

- Animal identification

- Geographic coordinates and datum

of the animals's capture site

- Conservation status of the carcass

- Clinical suspicion (if any)

- Macroscopic description of the changes observed and of the organs that did not present any apparent lesion (describe size, color, color pattern, size of the lesion, lesion distribution pattern, relationship with other organs and other characteristics deemed important)

- Macroscopic morphological diagnosis

- Preliminary cause of death

- Description of samples taken and tests to be performed

Figure 8. Necropsy report sheet model.

Groenendijk, J., Duplaix, N., Marmontel, M., Van Damme, P. and Schenck, C. (2015) Pteronura brasiliensis. The IUCN Red List of Threatened Species 2015: e.T18711A21938411. https://doi. org/10.2305/IUCN.UK.2015-2.RLTS.T18711A21938411.en. Downloaded on 01 March 2021.

ICMBio/MMA. Instituto Chico Mendes/Ministério Meio Ambiente (2010) Sumário Executivo do Plano de Ação Nacional para a Conservação da Ariranha. www.gov.br/icmbio/pt-br/assuntos/ biodiversidade/pan/pan-ariranha/1-ciclo/pan-ariranha-sumario.pdf

Koepfli, K.P. and Wayne, R.K. (1998) Phylogenetic relationships of otters (Carnivora: Mustelidae) based on mitochondrial cytochrome $b$ sequences. Journal of Zoology 246: 410-416.

Leuchtenberger, C., Barocas, A., Thoisy, B., Ward, C., Evangelista, E., Michalski, F., Trujillo, F., Georgiadis, G., Mourão, G., Gil, G., Groenendijk, J., Mendoza, J., Rheingantz, M.L., Buschiazzo, M., Marmontel, M., Damme, P.V., Wallace, R., Boher, S., Martino, S., Pereira, T.S. and Utreras, V. (2018) Giant Otter. Pages 74-81 in Duplaix, N. and Savage, M. (Orgs), The Global Otter Conservation Strategy. 1ed. IUCN/SSC Otter Specialist Group, Oregon, 1.

Matushima, E.R. (2007) Técnicas necroscópicas. Pages 983-990 in Cubas, Z.S., Silva, J.C.R. and Catão-Dias, J.L. (Eds) Tratado de Animais Selvagens: Medicina veterinária. 1ed. Editora Roca, São Paulo, Brazil.

Myers, G. (2012) Summary of Veterinary Care Guidelines for Otters in Zoos, Aquariums, Rehabilitation, and Wildlife Centers. IUCN/SSC Otter Specialist Group's, Otters in Zoos, Aquaria, Rehabilitation, and Wildlife Sanctuaries Task Force (OZ). 17 pp. http://www. otterspecialistgroup.rg/Library/TaskForces/OCT.html

Oliveira, G.C., Barcellos, J.F.M., Lazzarini, S.M. and Rosas, F.C.W. (2011) Gross anatomy and histology of giant otter (Pteronura brasiliensis) and Neotropical otter (Lontra longicaudis) testes. Animal Biology 61: 175-183.

https://doi.org/10.1163/157075511X566506

Pickles, R.S.A., Groombridge, J.J., Zambrana Rojas, V.D., Van Damme, P., Gottelli, D., Ariani, C.V. and Jordan, W.C. (2012) Genetic diversity and population structure in the endangered giant otter. Conservation Genetics 13: 235-245.

https://doi.org/10.1007/s10592-011-0279-9

Rheingantz, M.L. and Trinca, C.S. (2015) Lontra longicaudis. The IUCN Red List of Threatened Species 2015:e. T12304A21937379. https://doi.org/10.2305/IUCN.UK.2015- 
2.RLTS.T12304A21937379.en Downloaded on 01 March 2021.

Rheingantz, M., Waldemarin, H., Rodrigues, L. and Moulton, T.

(2011) Seasonal and spatial differences in feeding habits of the Neotropical otter (Lontra longicaudis) (Carnivora: Mustelidae) in a costal catchment of southeastern Brazil. Zoologia 28(1): 37-44. https://doi.org/10.1590/S1984-46702011000100006

Rodrigues, L., Leuchtenberger, C. and da Silva, V.M.F. (2013) Avaliação do risco de extinção da ariranha Pteronura brasiliensis (Zimmermann, 1780) no Brasil. Biodiversidade Brasileira 3(1): 228-239.

Silveira, L., Furtado, M.M., Rosas, F.W., Silva, L.C.L.C., Cabral, M.M.M., Torres, N.M., Sollmann, R., Kouba, A. and Jácomo, A.T.A. (2011) Tagging giant otters (Pteronura brasiliensis) (Carnivora, Mustelidae) for radio-telemetry studies. Aquatic Mammals 37(2): 208-212. https://doi.org/10.1578/AM.37.2.2011.208

Simpson, V. (2001) Post mortem protocol for otters. Pages 159-166 in Conroy, J.W.H., Yoxon, P. and Gutleb, A.C. (Eds) Proceedings of the First Otter Toxicology Conference. Journal of the International Otter Survival Fund Vol 1. 